\title{
Study on the Calculation of the Post-construction Settlement after the Secondary Preloading of Sand Pile Composite Foundation of the High- speed Railway
}

\author{
ZUO Shen ${ }^{1}, \mathrm{LI} \mathrm{Jin}^{2}$ and ZHANG Li ${ }^{3}$ \\ 1 Shandong jiaotong university, Jinan, China \\ 2 Shandong jiaotong university, Jinan, China \\ 3 Shandong jiaotong university, Jinan, China
}

\begin{abstract}
To complete the technology upgrade of the Kunshan section of the Beijing-Shanghai Railway, the secondary preloading of the original sand pile foundation was carried out in five years after the completion of the railway. Whether the control requirements of the post-construction settlement of the upgraded railway could be met was the key. Therefore, in this paper, the author analyses the consolidation deformation law of the sand pile foundation, sets up the membership function to describe the conversion from the drainage by consolidation to the composite foundation based on the Ascend Semi-cauchy Distribution Function of the Fuzzy Mathematics Theory, puts forward the time expression of the consolidation degree, verifies the computational accuracy of the expression by measured data and confirms that the e-lop curve method which considers the historical influence of the soil stress is more accurate in calculating the total settlement of the secondary preloading after comparison and calculation because this method can achieve the precise calculation of the post-construction settlement with the expression of degree of consolidation mentioned above.
\end{abstract}

\section{Introduction}

Please Sand pile composite foundation is a kind of bulk solid pile composite foundation which has been applied earlier. It is applicable to the compaction of the loose sand, silt, cohesive soil, plain fill, miscellaneous fill and other foundation treatment and is widely used in highways, railways, housing building and other infrastructure construction.

Therefore, the study on sand pile is significant in construction technology [1], [2], reinforcement mechanism [3]-[5], and design calculation [6]-[8], which has relatively mature theories and practical experience. However, applied research in railways is still rare. Because of the extremely strict control requirements of the post-construction settlement of the high-speed railways, the rigid pile which is safer and more conservative is used more in foundation treatment. Since the sand pile has a low bearing capacity and the consolidation deformation takes a long time, it often cannot meet the demand of the subgrade construction of the railways.

The testing section of Kunshan of the BeijingShanghai Railway was originally planned to adopt the ballast track. The control standard of the postconstruction settlement of the general subgrade was no more than $10 \mathrm{~cm}$. Sand pile-net composite foundation and surcharge preloading were used for reinforcement. After that, ballastless track was used in the subgrade. The control standard of the post-construction settlement was raised to $15 \mathrm{~mm}$ or less than $15 \mathrm{~mm}$. Thus, the surcharge preloading was carried out in the original testing section for the second time without changing the reinforcement measures relying on the sand pile-net composite foundation. Whether the control requirements of the postconstruction settlement of the railway could be met became the key. Therefore, the calculation of the postconstruction settlement after the secondary preloading of sand pile composite foundation which has been put aside for five years is demanded to be highly accurate. Nowadays, the settlement calculation method of the sand pile is mainly applied to harbors, highways, housing building and other fields. It is difficult to satisfy the strict standard of no more than $15 \mathrm{~mm}$. Therefore, in this paper, the author analyses the consolidation deformation law of the sand pile foundation, considers the historical influence that the secondary preloading exerts on the soil stress, puts forward the degree of consolidation and the calculation of the total settlement, which provides suggestions and help to the sand pile foundation in the field of railways.

\section{General introduction to the test}

The foundation of the testing section belongs to the quaternary holocene alluvia (Q4al). The surface layer is 
the yellowish clay which is in soft-hard plastic state and is $0.76-3.60 \mathrm{~m}$ thick. Below is the muddy silty clay which is dark gray and in fluidity plastic state. It contains a small amount of humus and thin silt on the local scale. It is of high compressibility and thixotropy and low strength. The thickness ranges between 3.2 meters to 16.5 meters. The substratum is made up of clay, silt and silty clay and it is in soft-hard plastic state. The foundation of the testing section is 13.8-meter-wide. In consideration of the settlement of the embankment and the post-construction settlement of foundation, 0.2 meters have been widened on each side and the distance between centers of tracks made 5.0 meters. The height of the embankment filling ranges between 4.2 meters to 5.5 meters. The slope ratio of the side slope of the embankment is $1: 1.5$ The slope surface of the side slope is defended with geosynthetic fiber mattress to enforce the soil and protected by planting grasses by spraying sowing. During filling the embankment, geogrids have been placed every 0.3 meters within 2.5 meters of the side scope. The reinforced length of the sand pile-net composite foundation is 124.7 meters and the reinforcement measures are shown in Table 1. Preloading of the sand pile-net composite foundation of the Kunshan section has been carried out for two times, which is shown in Table 2.

Table 1. The reinforcement measures of the sand pile-net composite foundation.

\begin{tabular}{|l|l|l|l|l|l|}
\hline $\begin{array}{l}\text { Reinforce- } \\
\text { ment } \\
\text { measures }\end{array}$ & $\begin{array}{l}\text { Pile } \\
\text { spaci- } \\
\mathrm{ng} \\
\mathrm{/m}\end{array}$ & $\begin{array}{l}\text { Pile } \\
\text { Dia- } \\
\text { meter } \\
/ \mathrm{m}\end{array}$ & $\begin{array}{l}\text { Reinforced } \\
\text { depth/m }\end{array}$ & $\begin{array}{l}\text { Pile } \\
\text { arrange- } \\
\text { ment }\end{array}$ & Notes \\
\hline $\begin{array}{l}\text { Sand pile- } \\
\text { net } \\
\text { composite } \\
\text { foundation }\end{array}$ & 2.0 & 0.4 & 15.0 & Quincunx & $\begin{array}{l}\text { O.6- } \\
\text { meter- } \\
\text { thick } \\
\text { sand } \\
\text { cushion, } \\
\text { a layer of } \\
\text { geogrids }\end{array}$ \\
\hline
\end{tabular}

Table 2. Two preloading of the sand pile-net composite foundation.

\begin{tabular}{|c|l|l|l|l|l|l|}
\hline $\begin{array}{l}\mathrm{N} \\
\mathrm{o} \\
\cdot\end{array}$ & $\begin{array}{l}\text { The time } \\
\text { of } \\
\text { beginning } \\
\text { loading }\end{array}$ & $\begin{array}{l}\text { The time } \\
\text { of stopping } \\
\text { loading }\end{array}$ & $\begin{array}{l}\text { The } \\
\text { height } \\
\text { of } \\
\text { loading }\end{array}$ & $\begin{array}{l}\text { Obse- } \\
\text { rvatio } \\
\mathrm{n} \\
\text { time }\end{array}$ & $\begin{array}{l}\text { The time } \\
\text { of } \\
\text { unloading }\end{array}$ & $\begin{array}{l}\text { The } \\
\text { height } \\
\text { of over- } \\
\text { loading }\end{array}$ \\
\hline 1 & $2003-5-19$ & $\begin{array}{l}2003-10- \\
17\end{array}$ & $6.29 \mathrm{~m}$ & $379 \mathrm{~d}$ & $/$ & 0 \\
\hline 2 & $2008-9-30$ & $\begin{array}{l}2008-10- \\
16\end{array}$ & $2 \mathrm{~m}$ & $380 \mathrm{~d}$ & $2009-7-12$ & $2 \mathrm{~m}$ \\
\hline
\end{tabular}

\section{Consolidatio calculation of sand pile composite foundation}

The sand pile-net composite foundation meets the requirement for post-construction settlement of the ballast track subgrade after the second preloading in September 30th, 2008, 1810 days after the first preloading in October 17th, 2003. How the settlement of the sand pilenet composite foundation develops in five years after the first preloading, whether the secondary preloading is necessary or not, how the calculation method of the total settlement after the secondary preloading influences the preloading measures of the sand pile-net composite foundation with low and medium compressibility are of great significance.

\subsection{Introduction of the consolidation deformation law}

The law of how the settlement of the sand pile-net composite foundation develops in five years after the first preloading is the variation characteristic of the consolidation. Based on the consolidation theory of the sand drained foundation and the composite foundation, and the Ascend Demi-cauchy Distribution Function of the Fuzzy Mathematics Theory which describes the degree of how the sand pile-net composite foundation is attached to the vertical drains foundation and the composite foundation at some point, the time expression of the consolidation degree of the sand pile-net composite foundation is proposed. The key to this expression is the membership function of the Fuzzy Theory. In this paper, $\beta$, which is in $U=1-\alpha \cdot e^{-\beta \cdot t}$, expresses how the sand pile foundation is attached to the vertical drains foundation and the composite foundation. According to the measured value of the settlement in equal time intervals, how $\beta$ changes along with the change of $t$ is shown in Figure 1. The expression is shown as follows:

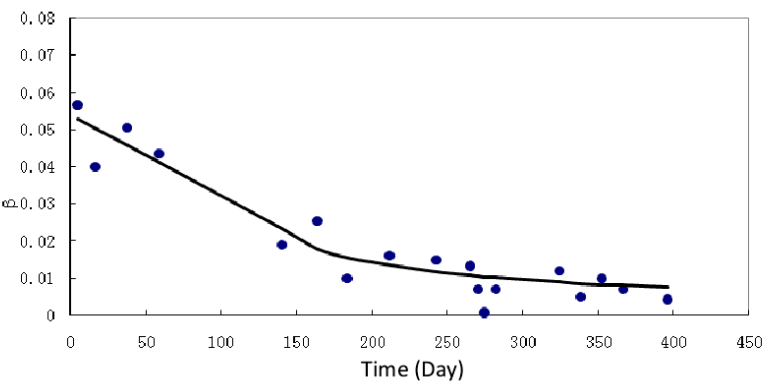

Figure 1. Trend graph on $\beta$-t of the sand pile-net composite foundation.

$\beta$ of the sand drained foundation generally ranges between 0.04 and 0.07 ( 1 per day) and that of the cementsoil pile composite foundation ranges between 0.001 and 0.003 (1 per day). The independent variable of the Ascend Demi-cauchy Distribution Function, however, mainly ranges between 1 and 60 . Given this, in this paper, $\beta^{\prime}(1000 \beta)$ is the independent variable. Then the function that describes the degree of how the sand pile foundation is attached to the vertical drains foundation is shown as follows:

$$
\begin{gathered}
\beta(t)=\left\{\begin{array}{lc}
-0.00022 t+0.0549 & 0 \leq t \leq 164 \\
0.3 \times(t-83.369)^{-0.6419} & t>164
\end{array}\right. \\
\mu_{A}\left(\beta^{\prime}\right)= \begin{cases}0 & \left(0 \leq \beta^{\prime} \leq 1\right) \\
\frac{0.03\left(\beta^{\prime}-1\right)^{2}}{1+0.03\left(\beta^{\prime}-1\right)^{2}} & \left(1<\beta^{\prime}<60\right) \\
1 & \left(\beta^{\prime} \geq 60\right)\end{cases}
\end{gathered}
$$

According to related parameters of the fracture surface, the time expressions of the sand drained foundation and composite foundation are respectively:

$$
U_{\text {井 }}(t)=1-0.469 \times \exp (-t / 12.45)-0.323 \times \exp (-t / 80.58)
$$




$$
U_{\text {复 }}(t)=1-0.7778 \times \exp (-t / 370.81)
$$

According to (2) (4) and (5), the expression of the consolidation degree of the sand pile-net composite foundation at time $t$ can be worked out as follows:

$$
U(t)=\mu_{A}\left(\beta^{\prime}\right) \cdot U_{\text {井 }}(t)+\left[\left(1-\mu_{A}\left(\beta^{\prime}\right)\right)\right] \cdot U_{\text {复 }}(t)
$$

In the expression:

$\mathrm{U}(\mathrm{t})$ : The consolidation degree of soft foundation reinforced by sand pile at time $t$.

$\mathrm{U}$ 井 $(\mathrm{t})$ : The consolidation degree of foundation at time $\mathrm{t}$ according to the vertical drains theory.

$\mathrm{U}$ 复 $(\mathrm{t})$ : The consolidation degree of foundation at time $t$ according to the consolidation theory of composite foundation.

$\mu_{A}\left(\beta^{\prime}\right)$ : The membership function that describes to what extent the sand pile foundation can be regarded as the sand drained foundation. In the function, $\beta^{\prime}$ is equal to $1000 \beta$.

\subsection{Application of consolidation deformation law}

According to Table 3 and Table 4, the estimated value of the post-construction settlement of the foundation center when $\mathrm{t}$ is $366 \mathrm{~d}$ is $64.5 \mathrm{~mm}$ while the predicted value is 57 $\mathrm{mm}$. It shows that the estimated value based on the Ascend Demi-cauchy Distribution Function of the Fuzzy Theory is slightly larger than the predicted value, which is much safer. The relative error between them is $13.1 \%$, so it can be used in the calculation of post-construction settlement.

Table 3. The estimated value of consolidation degree based on the Ascend Demi-cauchy Distribution Function of the Fuzzy Theory.

\begin{tabular}{|l|l|l|l|l|l|l|l|}
\hline Time/d & 0 & 150 & 366 & 500 & 1000 & 1500 & 1963 \\
\hline $\begin{array}{l}\text { Degree of } \\
\text { consolidation/\% }\end{array}$ & 0 & 68.1 & 82.6 & 83.5 & 91.4 & 95.0 & 95.9 \\
\hline
\end{tabular}

Table 4. The predicted value of the post-construction settlement after the first preloading (Unit:mm).

\begin{tabular}{|c|l|l|l|l|l|}
\hline \multicolumn{2}{|l|}{ Location } & $\begin{array}{l}\text { Three- } \\
\text { point } \\
\text { method }\end{array}$ & $\begin{array}{l}\text { Hyperbolic } \\
\text { method }\end{array}$ & $\begin{array}{l}\text { Asaoka } \\
\text { Method }\end{array}$ & $\begin{array}{l}\text { GM(1,1) } \\
\text { Method }\end{array}$ \\
\hline $\begin{array}{l}\text { The } \\
\text { foundation } \\
\text { center } \\
\text { (314) }\end{array}$ & $\begin{array}{l}\text { The } \\
\text { estimated } \\
\text { value of the } \\
\text { total } \\
\text { settlement }\end{array}$ & 359 & 371 & 351 & 351 \\
\cline { 2 - 6 } & $\begin{array}{l}\text { Post- } \\
\text { construction } \\
\text { settlement }\end{array}$ & 45 & 57 & 37 & 37 \\
\hline $\begin{array}{l}\text { The left } \\
\text { observation } \\
\text { pile } \\
\text { (283) }\end{array}$ & $\begin{array}{l}\text { The } \\
\text { estimated } \\
\text { value of the } \\
\text { total } \\
\text { settlement }\end{array}$ & 310 & 331 & 309 & 308 \\
\cline { 2 - 6 } & $\begin{array}{l}\text { Post- } \\
\text { construction } \\
\text { settlement }\end{array}$ & 27 & 48 & 26 & 25 \\
\hline $\begin{array}{l}\text { The } \\
\text { estimated } \\
\text { value of the } \\
\text { total } \\
\text { settlement }\end{array}$ & 292 & 308 & 288 & 289 \\
\cline { 2 - 6 } & $\begin{array}{l}\text { Post- } \\
\text { conservatruction } \\
\text { pile } \\
\text { settlement }\end{array}$ & 27 & 43 & 23 & 24 \\
\hline
\end{tabular}

Up to September 30, 2008 (when $t$ is 1963d), the estimated value of the post-construction settlement based on the Ascend Demi-cauchy Distribution Function of the Fuzzy Theory is $15.25 \mathrm{~mm}$, which does not meet the control standard of the post-construction settlement of the ballast track subgrade. Therefore, the secondary preloading has been carried out to the sand pile-net composite foundation in the primary test.

The settlement from the first preloading on May 19, 2003 to the end of the second unloading on October 15, 2009 is shown in Figure 2. The deadline of observing the settlement during the first preloading is when $t$ is $366 \mathrm{~d}$. The settlement from the deadline to the secondary preloading (when $t$ is 1963d) is estimated based on the Ascend Demi-cauchy Distribution Function of the Fuzzy Theory.

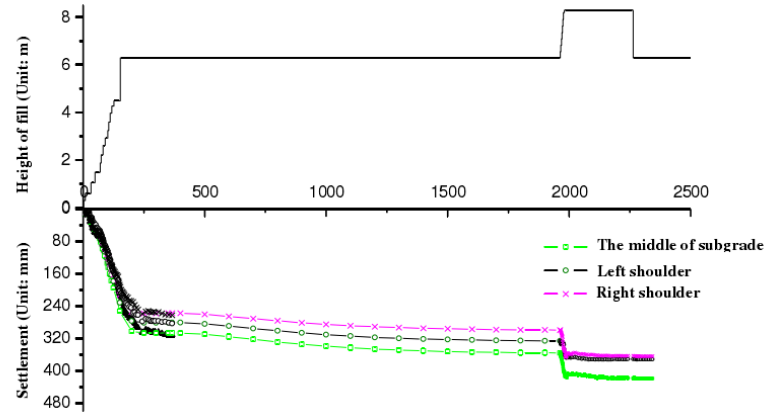

Figure 2. The settlement of the first and secondary preloading of testing section of Kunshan.

According to Table 5, the predicted value of the tota settlement of the foundation center after the second preloading is $68.60 \mathrm{~mm}$ while that of the residual settlement after the first preloading is $15.25 \mathrm{~mm}$, so the value of the total settlement after the second preloading is $53.35 \mathrm{~mm}$.

As is shown in Table 5, the completion rate of the settlement after the end of the secondary filling is very high. 30 days later, the rate is $76 \%-89.2 \% ; 180$ days later, the rate is $91.7 \%-95.3 \% ; 320$ days later, the rate is $93.1 \%-99.6 \%$. That is, from the end of filling to the stabilization of the settlement, the completion rate can be regarded as $91.7 \%-93.1 \%$. Therefore, the postconstruction settlement can be figured out based on the completion rate after the filling in a certain time and the total settlement.

Table 5. The completion rate of the settlement after the

\begin{tabular}{|c|c|c|c|c|}
\hline \multicolumn{2}{|l|}{ Location } & $\begin{array}{l}\text { The } \\
\text { foundation } \\
\text { center }\end{array}$ & $\begin{array}{l}\text { The left } \\
\text { observation } \\
\text { pile }\end{array}$ & $\begin{array}{l}\text { The right } \\
\text { observatio } \\
\text { n pile }\end{array}$ \\
\hline \multicolumn{2}{|c|}{$\begin{array}{l}\text { The predicted value of the total } \\
\text { settlement } / \mathrm{mm}\end{array}$} & 68.60 & 46.01 & 66.78 \\
\hline \multirow{2}{*}{$\begin{array}{l}\text { At the end } \\
\text { of the } \\
\text { secondary } \\
\text { filling }\end{array}$} & $\begin{array}{l}\text { The measured } \\
\text { value of the } \\
\text { settlement } / \mathrm{mm}\end{array}$ & 48.1 & 27.97 & 50.17 \\
\hline & $\begin{array}{l}\text { The completion } \\
\text { rate of the } \\
\text { settlement } \%\end{array}$ & 70.1 & 60.8 & 75.1 \\
\hline $\begin{array}{l}30 \text { days } \\
\text { after the } \\
\text { end of the } \\
\text { secondary }\end{array}$ & $\begin{array}{l}\text { The measured } \\
\text { value of the } \\
\text { settlement } / \mathrm{mm}\end{array}$ & 52.43 & 40.05 & 52.43 \\
\hline
\end{tabular}
secondary preloading. 


\begin{tabular}{|c|c|c|c|c|}
\hline filling & $\begin{array}{l}\text { The completion } \\
\text { rate of the } \\
\text { settlement } \%\end{array}$ & 76.4 & 87.0 & 89.2 \\
\hline \multirow{2}{*}{$\begin{array}{l}180 \text { days } \\
\text { after the } \\
\text { end of the } \\
\text { secondary } \\
\text { filling }\end{array}$} & $\begin{array}{l}\text { The measured } \\
\text { value of the } \\
\text { settlement } / \mathrm{mm}\end{array}$ & 62.9 & 46.04 & 63.66 \\
\hline & $\begin{array}{l}\text { The completion } \\
\text { rate of the } \\
\text { settlement } \%\end{array}$ & 91.7 & 100 & 95.3 \\
\hline \multirow{2}{*}{$\begin{array}{l}320 \text { days } \\
\text { after the } \\
\text { end of the } \\
\text { secondary } \\
\text { filling }\end{array}$} & $\begin{array}{l}\text { The measured } \\
\text { value of the } \\
\text { settlement } / \mathrm{mm}\end{array}$ & 63.81 & 45.84 & 64.85 \\
\hline & $\begin{array}{l}\text { The completion } \\
\text { rate of the } \\
\text { settlement } \%\end{array}$ & 93.1 & 99.6 & 97.1 \\
\hline
\end{tabular}

\subsection{Calculation of total settlement after the secondary preloading of the sand pile foundation}

The total settlement is composed by instantaneous settlement, primary consolidation settlement and secondary consolidation settlement. The instantaneous settlement is calculated according to the elastic theory. Based on the layer-wise summation method, the primary consolidation settlement is calculated according to the coefficient of compression, modulus of compression, e-p or e-lgp compression curve. In this paper, the results according to e-p or e-lgp compression curve are compared and the calculation method of the total settlement is finally determined.

\section{(1)E-p Curve}

Hyperbolic equation describes the test curve of the relationship between the soil's stress and strain. As the research suggests, the relationship between compressive strain ( $\mathcal{E}$ ) and effective consolidation stress (p) also satisfy the equation.

$$
\varepsilon=\frac{p}{A+B p} \quad \text { or } \quad \frac{1}{\varepsilon}=\frac{A}{p}+B
$$

$\varepsilon$-the compressive strain; p-the compressive stress; $\mathrm{A}$ and $\mathrm{B}$-undetermined coefficients.

According to the compression test, the relationship between compressive strain and void ratio is:

$$
\varepsilon=\frac{e_{0}-e}{1+e_{0}}
$$

Therefore, A and B can be figured out via least square method based on e-p curve.

$$
e=e_{0}-\varepsilon\left(1+e_{0}\right)=e_{0}-\frac{\left(1+e_{0}\right) p}{A+B p}
$$

1810 days after the end of the first filling, effective consolidation stress ( $p$ ) of each soil layer can be regarded as the additional stress $\left(\sigma_{s}\right)$ at the corresponding depth. The pore water pressure is ignored at the beginning of the second filling. According to the e-p compression test at different depth, the void ratio $\mathrm{e} 0$ ' when the effective consolidation stress is $\sigma_{s}$ can be figured out, which is the initial void ratio of soil at the beginning of the second filling. Let the effective consolidation stress at the very beginning of the secondary preloading be $\sigma_{s 1}{ }^{i}$ and the effective consolidation stress after the secondary preloading be $\sigma_{s 1}{ }^{i}+\Delta p^{i}$. The total settlement after the secondary preloading can be figured out based on the e-p curve when $\Delta p^{i}$ is the subsidiary stress of the secondary preloading at the corresponding depth. The calculation process of the e-p curve is shown in Figure 3.

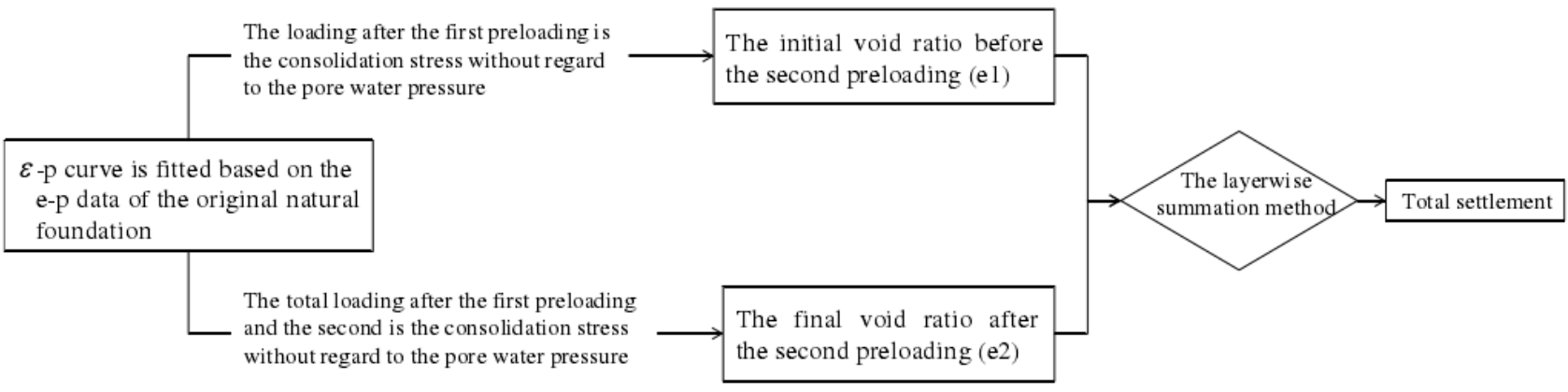

Figure 3. The calculation flow chart of the e-p curve.

According to Table 6, the total settlement after the secondary preloading is $191.3 \mathrm{~mm}$ based on the e-p curve while the predicted value is $53.35 \mathrm{~mm}$. That is, the calculated value is 3.6 times as large as the predicted one because of the ignorance of the effect that the stress history makes on the settlement in calculation. Therefore, the e-p curve is unfit for the calculation of the total settlement of the secondary settlement.

Table 6. The calculation results of the secondary preloading based on the e-p curve.

\begin{tabular}{|c|l|l|l|l|}
\hline $\begin{array}{l}\text { Number } \\
\text { of layer }\end{array}$ & $\begin{array}{l}\text { Thickness } \\
\text { of layer/m }\end{array}$ & $\begin{array}{l}\text { Initial void } \\
\text { ratio (e1) }\end{array}$ & $\begin{array}{l}\text { Final void } \\
\text { ratio (e2) }\end{array}$ & $\begin{array}{l}\text { Layered } \\
\text { settlement/mm }\end{array}$ \\
\hline$(1)$ & 2.86 & 0.811 & 0.792 & 31.61 \\
\hline$(2)$ & 3.24 & 0.946 & 0.919 & 47.84 \\
\hline$(3)-3$ & 5.63 & 0.652 & 0.644 & 28.20 \\
\hline$(3)-4$ & 4.37 & 0.876 & 0.863 & 30.34 \\
\hline$(3)-5$ & 6.68 & 0.829 & 0.815 & 53.36 \\
\hline
\end{tabular}

(2) E-logp Curve

E-logp curve shows the stress history of soil. The calculation process of the initial void ratio (e1) before the secondary preloading is the same as that of the e-p curve method. Underground water is two meters below the 
earth's surface. Because the first preloading makes the pre-consolidation stress of the second preloading increase,
The calculation process of the e-lop curve is shown in Figure 4:

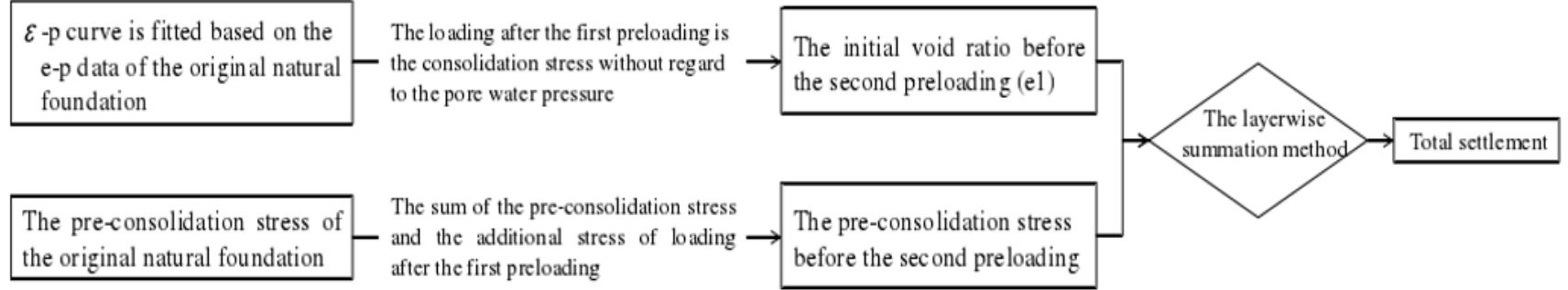

Figure 4. The calculation flow chart of the e-lop curve.

Table 7. The calculation results of the secondary preloading based on the e-lop curve.

\begin{tabular}{|l|l|l|l|l|l|}
\hline $\begin{array}{l}\text { Numbe } \\
\text { r of } \\
\text { layer }\end{array}$ & $\begin{array}{l}\text { Thickness } \\
\text { of layer/m }\end{array}$ & $\begin{array}{l}\text { Compre- } \\
\text { ssion } \\
\text { index }\end{array}$ & $\begin{array}{l}\text { Swelling } \\
\text { index }\end{array}$ & $\begin{array}{l}\text { Pre- } \\
\text { consolidation } \\
\text { stress/kPa }\end{array}$ & $\begin{array}{l}\text { Layered } \\
\text { settleme } \\
\text { nt }\end{array}$ \\
\hline$(1)$ & 2.86 & 0.25 & 0.03 & 332.03 & 4.83 \\
\hline$(2)$ & 3.24 & 0.30 & 0.04 & 212.79 & 23.87 \\
\hline$(3)-3$ & 5.63 & 0.14 & 0.06 & 372.89 & 13.27 \\
\hline$(3)-4$ & 4.37 & 0.2 & 0.02 & 396.64 & 2.37 \\
\hline$(3)-5$ & 6.68 & 0.33 & 0.02 & 345.67 & 2.82 \\
\hline
\end{tabular}

According to Table 7 , the total settlement is about $47.16 \mathrm{~mm}$ based on the e-logp curve that considers the historical influence of the stress while the measured value is $53.35 \mathrm{~mm}$ which is slightly larger than the former. The relative error is $11.6 \%$. Because e-logp curve method do not take the settlement caused by lateral displacement into consideration, the value of total settlement based on the e-logp curve method is slightly smaller than the measured. Therefore, e-logp curve method can meet the engineering requirements in calculating the total settlement after the secondary loading.

\section{Conclusion}

In this paper, the author takes the testing section of Kunshan of the Beijing-Shanghai Railway as an example and studies the calculation of the settlement of the sand pile composite foundation after the secondary preloading which has been put aside for a long time. The conclusion is shown as follows.

(1) The consolidation characteristics of the settlement of the sand pile foundation change over time. That is, drainage by consolidation turns into composite foundation. Based on the Ascend Demi-cauchy Distribution Function of the Fuzzy Mathematics Theory which describes the degree of how the sand pile foundation is attached to the vertical drains foundation and the composite foundation at some point, the time expression of the consolidation degree of the sand pile foundation is proposed. The expression is proved to be of higher accuracy by measured data.

(2) After comparison, the e-lop curve method which considers the historical influence of the soil stress is more accurate in calculating the total settlement after the secondary preloading. The post-construction settlement of the railway can be figured out with the expression of degree of consolidation mentioned in this paper.

\section{References}

1. Huang Ruijiang. The application of composite foundation in solving the problem of bridge bump. Journal of China \& Foreign Highway, Vol.4, pp : 188-190, April 2007

2. Li Tao, etc. The construction technology on the foundation strengthening of the open caisson of the north anchorage of the Fourth Nanjing Yangtze Bridge. Journal of Highway,Vol.6, pp: 20-25.July 2010

3. Zheng Junjie, etc. The laboratory model experiment on the multi-element composite foundation with steel pipe pile and sand pile. Journal of Huazhong University of Science and Technology (Natural Science Edition), Vol.9, pp : 121-124.September 2008

4. Linfei, Performance evaluation of the sand compaction pile of the expressway in dealing with the liquefied soil.. Journal of Highway Traffic Science and Technology (Application Technology Edition), Vol.10, pp: 125-127. October 2010

5. Wang Xianzhi, Zheng Junjie and Li Xiangdong, Study on the laboratory model experiment of the sand pile composite foundation. Journal of Huazhong University of Science and Technology (Urban Science Edition), Vol.04, pp : 22-25. April 2007

6. Zhao Shouxian, The calculation methods of the settlement of sand pile composite foundation based on CPT. Journal of Geotechnical Engineering World, Vol.06, pp : 36-39. July 2007

7. Zhang xi, Wu Xinyi and Yin Haiqing. Reinforcement mechanism of compacting sand pile underwater and calculation methods of the settlement.. Journal of Chinese Harbour Engineering, 2010 Vol.S1, pp: 148150.Janury 2010

8. Gu Xiangkui, Wang Xiaohui. The design of the composite foundation with compacting sand pile underwater of the gravity wharf. Port and Waterway Engineering, Vol.11, pp:227-231. November 2011 